\title{
ANALYSIS OF INDUSTRIES BECOMING SICK BY RATIO ANALYSIS
}

\author{
A.K.M. Solayman Hoque ${ }^{1, *}$, S.K. Biswas ${ }^{2}$ and M. A. Wazed ${ }^{3}$ \\ ${ }^{1}$ GEM Co. Ltd., Chittagong, Bangladesh \\ ${ }^{2}$ Department of Mech. \& Production Eng., Ahsanullah University of Science \& Technology, Bangladesh \\ ${ }^{3}$ Department of Mechanical Engineering, Chittagong University of Engineering \& Technology, Bangladesh \\ *Corresponding e-mail: solaymanhoq@gmail.com
}

\begin{abstract}
Industries becoming sick has become a great problem everywhere in this industrial world especially in the $3^{r d}$ world countries. Many researches have been done to analyze the problem and suggest opinions about solving this problem as huge amount of capital is lost if an industry becomes sick and go out of business. If the numbers become multiple, such happenings might affect national economy and thus it draws attention of political and business leaders besides new entrepreneurs of the country. In this paper an attempt has been made to analyze this problem by using financial ratio analysis. Various financial ratios of two numbers of medium and large industries of one industrial corporation in Bangladesh have been calculated by using actual financial data of the industries. The data has been analyzed and a correlation has been shown with various financial ratios with the industries becoming sick. The authors hope that the findings of the analysis will attract attention of academicians, industrialists, political leaders, and the owners of the industries which are becoming sick and will also show a guiding path to new entrepreneurs.
\end{abstract}

Keywords: Sick industries, financial ratios, operations of an industry in Bangladesh

\section{INTRODUCTION}

Ratio analysis is one of the tools of financial analysis. Using this tool one can analysis and say, whether an industry is a healthy unit or a sick unit. $^{1,2,3}$

Ratio analysis is defined as the systematic use of various ratios to interpret the financial statements so that the strength and weakness of a firm, as well as its historical performance and current financial condition can be determined.

\section{RATIOS}

Ratios used in this study are:

1. cash flow ratio,

2. Net income/ Profitability ratio,

3. Debt ratio,

4. Liquid assets/total assets ratio,

5. Current ratio,

6. Turnover ratio,

7. Cost ratio,

8. Altman ratio

9. Risk/Leverage ratio

Cash flow ratio: It is the ratio of cash flow (Profit before interest, tax and depreciation) to the sales or cash flow to the total assets or cash flow to the total debt.

Cash flow ratio $=$ Cash flow $/$ Sales

Profitability Ratio: Profitability ratio measures the success of the firm in earning a net return on sales or on investment. Since profit is the ultimate objective of the firm, poor performance here indicates a basic failure that, if not corrected, would probably result in the firm's going out of business.

Profit Margin $=$ Net income $/$ Sales

Debt ratio: This ratio equals total debt (Total liabilities) divided by total assets that can be calculated by using the balance sheet data.

Debt ratio $=$ Total debt $/$ Total assets

The debt to total assets ratio is also called debt ratio. Generally, creditors prefer a low debt ratio as it implies a greater protection of their position. A debt ratio generally means that the firm must pay a higher interest rate on its borrowing; beyond some point, the firm will not be able to borrow at all.

Liquid/total assets ratio: This is the ratio of current assets to the total assets.

Total assets ratio $=$ Current assets $/$ Total assets

Current ratio: The current ratio is the ratio of total current assets to total current liabilities. It is calculated by dividing current assets by current liabilities.

Current ratio $=$ Current assets $/$ Current liabilities Turnover ratio:

(a) Inventory turnover: Inventory turnover equals cost of goods sold divided by average inventory. Therefore, both balance sheet and income statement data must be used. Inventory level may be changed significantly during a known year and it is particularly important here to use a yearly average rather than the year end amount.

Inventory turnover $=$ Cost of goods sold $/$ Average inventory

(b) Fixed assets turnover: This ratio is computed by dividing net sales by fixed asset and equals: 
Fixed assets turnover $=$ Net sales $/$ Fixed assets Cost ratio: Cost ratio is the ratio of operating expenses to sales.

Cost ratio $=$ Operating expenses $/$ Sales

Altman's ratio: It is the ratio of profit before interest and tax to the total assets.

Altman ratio $=$ Profit before interest $/$ Total assets

Risk/Leverage Ratio: The term leverage may be defined as the employment of an asset or sources of funds for which the firm has to pay a fixed cost or fixed return. There are two types of leverage: Operating and Financial.

The leverage associated with investment activities is referred to as operating leverage.

Operating leverage $=$ Sales-stock consumed $/$ Profit before interest and tax

While leverage associated with financing activities is called the financial leverage.

Financial leverage $=$ Profit before interest and tax /Profit before tax

\section{CASE STUDIES}

\section{Case study 1: Company A}

It was established in mid-sixties by one of the then well-known Industrial group at its own cost. The industry is located at Dhaka. It was a private limited company initially. After liberation, the industry was declared as a nationalized industry. In early 70's Company A started its commercial production. The Industry has the following related information as shown in Table 1.

Table 1. Basic information of Company A

\begin{tabular}{|l|l|}
\hline Land area & 1.03 acres \\
\hline Authorized capital & 25.0 lac Taka \\
\hline Paid up capital & 17.0 lac Taka \\
\hline Attainable Capacity & 9.0 lac pcs \\
\hline Product & $\begin{array}{l}\text { Fluorescent Tube Light } \\
\text { 4'-00, 40 watt and } \\
\text { 2'-00, 20 watt }\end{array}$ \\
\hline Raw material & $\begin{array}{l}\text { Lampshell, Exhaust and } \\
\text { support tube, filament, } \\
\text { lead in wire, base cap, } \\
\text { chemicals (butyl acid), } \\
\text { argon gas, mercury gas } \\
\\
\text { etc. }\end{array}$ \\
\hline Annual production target & 7.0 lac pcs. \\
& \\
\hline
\end{tabular}

The firm's actual financial ratio data has been tabulated in Table 2, the conclusion has been discussed after the tabular results. We have used the following explanations for ratio keys: Ratio keys (explanation of keys is given in Appendix) are tabulated in first column and in subsequent columns results for the yearly period under consideration have been mentioned.

\section{Remarks on ratio analysis (Company A)}

Cash flow ratio: From the results of ratio keys 1,2 and 4 , it is found that the sample industry is in sick position as these ratios show gradual declination if considered on average basis and forgetting the occasional random fluctuations.

Net income ratio: From the results of ratio keys 5, 6 and 8 as shown below, it can be concluded that the sample industry is in sick position.

Debt/Total assets ratio: From the results of ratio key 9 and 11, we found that in the first four years though the industry seems to be in a little bit better position but the last four years' result show the industry again has become sick.

Liquid assets/ Total assets: From the ratio key 15, it is seen that the results continuously going on lower trend and our opinion is that the sample industry may survive.

Liquid assets/Current debt: Ratio key 19 is also used for prediction of sickness and from the result, we found that in last four financial years the trend is lower, i.e. the industry is becoming sick

Turnover ratio: Ratio 21, 24 and 26 are the keys for revival but from the result, it is seen that the sample industry might become sick. Ratio key 22 , it is the key for prediction of sickness and from the result we found that with respect to sickness the industry's position is not good at all. Ratio key 23 is the key for prediction of sickness as well as revival and from the result it can be said that the industry may survive.

Cost ratio: Ratio key 40, it is for prediction of sickness and from the result it is seen that the sample industry is becoming sick. Ratio key 44, it is for prediction of revival and from the result it is seen that the condition of the industry is becoming sick.

\section{Case Study 2:Company B}

The project was taken up 1965 on the basis of a feasibility report (prepared by a UK based firm), the project was financed under USSR credit. The implementation of the project was completed in late 70's. The plant came into operation in early 80 's. The project was converted into public limited company in 1979. The company has the data during establishment are shown in Table 3.

The same ratios mentioned in previous Section have been used in the study of Company B, and shown in Table 4.

\section{Remarks on ratio analysis (Company B)}

Cash flow ratio: From the results of ratio key 1, 2 and 4 , we can say that the sample industry may survive.

Net income ratio: From the results of ratio key 5, 6 and 8 , it is seen that, considering average values, 
Table 2. Actual financial ratio data: Company A

Group A: Prediction of Sickness

\begin{tabular}{|c|c|c|c|c|c|c|c|c|}
\hline Ratio key & $2003-04$ & $2004-05$ & $2005-06$ & $2006-07$ & $2007-08$ & $2008-09$ & $2009-10$ & $2010-11$ \\
\hline 7 & 0.04 & 0.03 & 0.01 & 0.01 & 0.02 & 0.01 & 0.01 & -0.04 \\
\hline 9 & 0.26 & 0.23 & 0.20 & 0.19 & 0.19 & 0.20 & 0.21 & 0.21 \\
\hline 11 & 0.36 & 0.33 & 0.30 & 0.29 & 0.30 & 0.31 & 0.37 & 0.37 \\
\hline 19 & 4.84 & 5.31 & 5.92 & 6.13 & 5.97 & 5.95 & 5.32 & 5.33 \\
\hline 22 & 0.28 & 0.27 & 0.46 & 0.55 & 0.63 & 0.77 & 0.51 & 0.67 \\
\hline 31 & 2.13 & 2.31 & 2.55 & 2.58 & 2.57 & 2.43 & 1.91 & 1.88 \\
\hline 33 & 1.81 & 1.85 & 1.80 & 1.05 & 1.17 & 2.71 & 2.56 & -0.48 \\
\hline 34 & 1.31 & 1.41 & 2.30 & 2.58 & 1.06 & 1.01 & 1.02 & 0.99 \\
\hline 35 & 2.37 & 2.61 & 4.14 & 2.69 & 1.24 & 2.74 & 2.10 & -0.48 \\
\hline 36 & 4.76 & 3.93 & 5.66 & 5.35 & 6.11 & 6.32 & 5.14 & 4.93 \\
\hline 40 & 0.24 & 0.24 & 0.29 & 0.44 & 0.38 & 0.46 & 0.44 & 0.61 \\
\hline
\end{tabular}

Group B: Prediction of Revival

\begin{tabular}{|c|c|c|c|c|c|c|c|c|}
\hline Ratio key & $2003-04$ & $2004-05$ & $2005-06$ & $2006-07$ & $2007-08$ & $2008-09$ & $2009-10$ & $2010-11$ \\
\hline 15 & 1.24 & 1.21 & 1.18 & 1.18 & 1.15 & 1.17 & 1.13 & 1.11 \\
\hline 21 & 0.01 & 0.02 & 0.01 & 0.03 & 0.04 & 0.05 & 0.14 & 0.12 \\
\hline 24 & 6.20 & 6.62 & 7.67 & 9.95 & 9.51 & 10.09 & 8.63 & 9.14 \\
\hline 26 & 4.99 & 5.48 & 6.49 & 8.45 & 8.24 & 8.64 & 7.64 & 8.21 \\
\hline 38 & 0.24 & 0.20 & 0.18 & 0.17 & 0.19 & 0.10 & 0.08 & -0.10 \\
\hline 44 & 0.12 & 0.10 & 0.09 & 0.06 & 0.06 & 0.05 & 0.07 & 0.05 \\
\hline
\end{tabular}

Group C: Prediction of Sickness as well as Revival

\begin{tabular}{|c|c|c|c|c|c|c|c|c|}
\hline Ratio key & $2003-04$ & $2004-05$ & $2005-06$ & $2006-07$ & $2007-08$ & $2008-09$ & $2009-10$ & $2010-11$ \\
\hline 1 & 0.18 & 0.16 & 0.15 & 0.17 & 0.21 & 0.12 & 0.12 & -0.14 \\
\hline 2 & 0.04 & 0.03 & 0.02 & 0.02 & 0.02 & 0.01 & 0.02 & -0.02 \\
\hline 4 & 0.10 & 0.09 & 0.08 & 0.07 & 0.09 & 0.05 & 0.04 & -0.05 \\
\hline 5 & 0.13 & 0.10 & 0.06 & 0.06 & 0.13 & 0.04 & 0.04 & -0.23 \\
\hline 6 & 0.03 & 0.02 & 0.01 & 0.01 & 0.02 & 0.01 & 0.01 & -0.03 \\
\hline 8 & 0.07 & 0.06 & 0.03 & 0.02 & 0.05 & 0.02 & 0.01 & -0.07 \\
\hline 23 & 0.24 & 0.30 & 0.26 & 0.16 & 0.18 & 0.17 & 0.58 & 0.25 \\
\hline 30 & 0.03 & 0.03 & 0.02 & 0.01 & 0.02 & 0.01 & 0.01 & -0.02 \\
\hline
\end{tabular}

the Sample industry may survive.

Debt/total assets ratio: From the results of ratio key 9 and 11 , it can be concluded that sample industry at present is in sick position.

Liquid/Total assets: Ratio key 15, it is for prediction of revival but from the results, it is seen that the sample industry's overall condition is not that good.

Liquid assets/Current debt: Ratio key 19, it is for prediction of sickness but from the result we can say that the sample industry is becoming sick.

Turnover ratio: Ratio key 21, 24, and 26 are the keys for revival, but from the result it is seen that the sample industry may survive. Ratio key 22 is the key for prediction of sickness but from results it is seen that the industry may survive. Ratio key 23 is the key for prediction of sickness as well as revival but from the result it can be opined that the industry may survive.

Cost ratio: Ratio key 40 is for prediction of sickness but it is seen that the results of the sample industry are reverse i.e., the industry may survive. Ratio key 44.is for prediction of revival, and from results it is seen that the condition of the industry is not that good.

Table 3. Basic information of Company B

\begin{tabular}{|l|l|}
\hline Land area & 107 acres \\
\hline Authorized capital & 75.0 crores Taka \\
\hline Paid up capital & 58.51 crores Taka \\
\hline Attainable Capacity & 1850 M. Ton \\
\hline Product & $\begin{array}{l}\text { Three phase transformer, 33/ } \\
\text { 11 KV, Circuit breaker, } \\
\text { Isolator, Lighting arrestor }\end{array}$ \\
\hline Raw material & $\begin{array}{l}\text { Silicon steel sheet, copper } \\
\text { strips, super enamel copper } \\
\text { wire, M.S. sheet, H.T } \\
\text { insulator, transformer oil etc. }\end{array}$ \\
\hline $\begin{array}{l}\text { Annual production } \\
\text { target }\end{array}$ & $\begin{array}{l}1875 \text { Nos. of 200 KVA } \\
\text { Transformers. }\end{array}$ \\
\hline
\end{tabular}

Therefore the general conclusion is that the condition of the Company $\mathrm{B}$ may be considered as still better, and it can be said that it may be possible to overcome the present problems at any time if corrective actions are taken. 
Table 4. Actual financial ratio data: Company B

Group A: Prediction of Sickness

\begin{tabular}{|c|c|c|c|c|c|c|c|c|}
\hline Ratio key & $2003-04$ & $2004-05$ & $2005-06$ & $2006-07$ & $2007-08$ & $2008-09$ & $2009-10$ & $2010-11$ \\
\hline 7 & -0.13 & -0.17 & -0.10 & -0.14 & -0.10 & -0.07 & -0.05 & -0.05 \\
\hline 9 & 0.54 & 0.80 & 0.91 & 1.13 & 1.66 & 4.44 & 7.18 & 13.17 \\
\hline 11 & 0.74 & 1.05 & 1.14 & 1.42 & 2.05 & 5.07 & 7.73 & 16.53 \\
\hline 19 & 1.20 & 0.88 & 1.02 & 0.93 & 0.85 & 0.81 & 0.78 & 0.78 \\
\hline 22 & 2.32 & 1.76 & 1.15 & 0.73 & 1.23 & 0.93 & 0.79 & 0.82 \\
\hline 31 & 1.67 & 1.49 & 1.29 & 1.22 & 1.06 & 0.66 & 0.60 & 0.46 \\
\hline 33 & 0.57 & 0.67 & 0.08 & 0.16 & -0.52 & 5.40 & 2.71 & 2.09 \\
\hline 34 & 0.71 & 0.77 & 0.59 & 0.58 & 0.43 & -0.24 & -0.96 & -1.65 \\
\hline 35 & 0.40 & 0.52 & 0.05 & 0.09 & -0.22 & -1.30 & -2.60 & -3.45 \\
\hline 36 & 5.08 & 3.93 & 3.12 & 2.78 & 2.91 & 3.97 & 4.69 & 2.82 \\
\hline 40 & 0.65 & 0.65 & 0.32 & 0.25 & 0.34 & 0.21 & 0.19 & 0.22 \\
\hline
\end{tabular}

Group B: Prediction of Revival

\begin{tabular}{|c|c|c|c|c|c|c|c|c|}
\hline Ratio key & $2003-04$ & $2004-05$ & $2005-06$ & $2006-07$ & $2007-08$ & $2008-09$ & $2009-10$ & $2010-11$ \\
\hline 15 & 0.65 & 0.71 & 0.93 & 1.05 & 1.41 & 3.59 & 5.58 & 10.35 \\
\hline 21 & 0.50 & 0.34 & 0.27 & 0.11 & 0.09 & 0.18 & 0.14 & 0.45 \\
\hline 24 & 3.37 & 2.73 & 1.73 & 1.07 & 1.57 & 1.36 & 1.17 & 1.40 \\
\hline 26 & 5.20 & 3.85 & 1.86 & 1.02 & 1.12 & 0.48 & 1.09 & 0.14 \\
\hline 38 & 0.96 & 1.17 & 0.83 & 0.96 & 0.77 & 0.65 & 0.57 & 0.34 \\
\hline 44 & 0.05 & 0.13 & 0.08 & 0.26 & 0.22 & 0.12 & 0.20 & 2.20 \\
\hline
\end{tabular}

GRUP C: Prediction of Sickness as well as Revival

\begin{tabular}{|c|c|c|c|c|c|c|c|c|}
\hline Ratio key & $2003-04$ & $2004-05$ & $2005-06$ & $2006-07$ & $2007-08$ & $2008-09$ & $2009-10$ & $2010-11$ \\
\hline 1 & -0.69 & -0.89 & -0.22 & -0.20 & -0.19 & -0.06 & -0.03 & -0.03 \\
\hline 2 & -0.13 & -0.23 & -0.12 & -0.20 & -0.17 & -0.15 & -0.03 & -0.22 \\
\hline 4 & -0.17 & -0.22 & -0.10 & -0.14 & -0.08 & -0.03 & -0.02 & -0.01 \\
\hline 5 & -0.83 & -1.03 & -0.28 & -0.24 & -0.25 & -0.11 & -0.05 & -0.05 \\
\hline 6 & -0.16 & -0.27 & -0.15 & -0.24 & -0.22 & -0.23 & -0.05 & -0.36 \\
\hline 8 & -0.21 & -0.25 & -0.13 & -0.17 & -0.11 & -0.04 & -0.03 & -0.02 \\
\hline 23 & 0.82 & 0.61 & 0.28 & 0.20 & 0.14 & 0.35 & 0.19 & 0.68 \\
\hline 30 & -0.21 & -0.33 & -0.21 & -0.33 & -0.35 & -0.51 & -0.14 & -1.31 \\
\hline
\end{tabular}

\section{CONCLUSION}

The ratio analysis method as outlined $\mathrm{in}^{2}$ is an important tool to predict the condition of a firm/industry from the point of view of the survival/getting sick. In this study the related financial ratios from actual data collected from the sources $^{4,5,6,7}$ related to the organization show the overall conditions of the industries which have been considered in the case study. We can conclude that although the overall condition of the Company $\mathrm{A}$ is relatively better than that of the Company $\mathrm{B}$, if proper corrective measures are taken both the companies may not become sick in near future ultimately. There might be errors in data source as collected from recorded books of industries ${ }^{4,5,6,7}$, and there are random fluctuations in data. In this study we considered only the overall average value ignored the sources of data recording and errors etc.

\section{REFERENCES}

1. M.Y. and Jain, P.K. "Financial Management", Ch. 6, page 79-122.

2. "Decision", A special issue on Industrial Sickness, Indian Institute of Management, Vol 6, Jan. 1979, India.

3.Lawrence D. Schall \& Charles W. Halley, Financial Management.

4. Annual Report, 2003 11, Company B.

5 MIS Report, 2003 11, Company B.

6. Annual Report, 2003 11, Company A.

7. MIS Report, 2003 11, Company A. 
APPENDIX

List of Ratios Used in the Study

Cash Flow Ratios

\begin{tabular}{|c|c|c|c|}
\hline Key & Adaptations/Defined as & & Remarks \\
\hline 1. & Cash flow/ Sales & $\begin{array}{l}\text { Profit before Interest, tax \& Depreciation } \\
\text { /Sales }\end{array}$ & $\begin{array}{l}\text { Lower trend indicates } \\
\text { sickness }\end{array}$ \\
\hline 2. & Cash Flow/ Total Assets & $\begin{array}{l}\text { Profit before Interest, tax \& Depreciation / } \\
\text { Capital Employed }\end{array}$ & $\begin{array}{l}\text { Lower trend indicates } \\
\text { sickness }\end{array}$ \\
\hline 3. & Cash Flow/ Net Worth & $\begin{array}{l}\text { Profit before Interest, tax \& Depreciation / } \\
\text { (Share Capital + Reserves ) }\end{array}$ & $\begin{array}{l}\text { Lower trend indicates } \\
\text { sickness }\end{array}$ \\
\hline 4. & Cash Flow/ Total Debt & $\begin{array}{l}\text { Profit before Interest, tax \& Depreciation / } \\
\text { (Deferred Liabilities + Current Liabilities) }\end{array}$ & $\begin{array}{l}\text { Lower trend indicates } \\
\text { sickness }\end{array}$ \\
\hline \multicolumn{4}{|c|}{ Net Income Ratios } \\
\hline 5. & Net Income / Sales & Profit before Tax / Sales & $\begin{array}{l}\text { Lower trend indicates } \\
\text { sickness }\end{array}$ \\
\hline 6. & Net Income / Total Assets & Profit before Tax / Capital Employed & $\begin{array}{l}\text { Lower trend indicates } \\
\text { sickness }\end{array}$ \\
\hline 7. & Net Income / Net Worth & $\begin{array}{l}\text { Profit before Tax / (Share Capital + } \\
\text { reserves) }\end{array}$ & $\begin{array}{l}\text { Lower trend indicates } \\
\text { sickness }\end{array}$ \\
\hline 8. & Net Income / Total Debt & $\begin{array}{l}\text { Profit before Tax / (Deferred Liabilities + } \\
\text { Current Liabilities) }\end{array}$ & $\begin{array}{l}\text { Lower trend indicates } \\
\text { sickness }\end{array}$ \\
\hline \multicolumn{4}{|c|}{ Debt/ Total Assets Ratios } \\
\hline 9. & Current Liabilities / Total Assets & $\begin{array}{l}\text { Total Current Liabilities / Capital } \\
\text { Employed }\end{array}$ & $\begin{array}{l}\text { Higher trend indicates } \\
\text { sickness }\end{array}$ \\
\hline 10. & $\begin{array}{l}\text { Long Term Liabilities / Total } \\
\text { Assets }\end{array}$ & Deferred Liabilities + Capital Employed & $\begin{array}{l}\text { Higher trend indicates } \\
\text { sickness }\end{array}$ \\
\hline 11. & $\begin{array}{l}\text { Current Liabilities + Long Term } \\
\text { Liabilities / Total Assets }\end{array}$ & $\begin{array}{l}\text { Deferred Liabilities + Total Current } \\
\text { Liabilities / Capital Employed }\end{array}$ & $\begin{array}{l}\text { Higher trend indicates } \\
\text { sickness }\end{array}$ \\
\hline 12. & $\begin{array}{l}\text { Current Liabilities + Long Term } \\
\text { Liabilities + Preference Stock / } \\
\text { Total Assets }\end{array}$ & $\begin{array}{l}\text { (Deferred Liabilities + Total Current } \\
\text { Liabilities + Preference Share) / Capital } \\
\text { Employed }\end{array}$ & $\begin{array}{l}\text { Higher trend indicates } \\
\text { sickness }\end{array}$ \\
\hline \multicolumn{4}{|c|}{ Liquid Assets / Total Assets } \\
\hline 13. & Cash / Total Assets & ( Cash + Bank) / Capital Employed & $\begin{array}{l}\text { Lower trend indicates } \\
\text { sickness }\end{array}$ \\
\hline 14. & Quick Assets / Total Assets & $\begin{array}{l}\text { ( Cash + Bank + Sundry Debtors ) / Capital } \\
\text { Employed }\end{array}$ & $\begin{array}{l}\text { Lower trend indicates } \\
\text { sickness }\end{array}$ \\
\hline 15. & Current Assets / Total Assets & Total Current Assets / Capital Employed & $\begin{array}{l}\text { Higher trend indicates } \\
\text { sickness }\end{array}$ \\
\hline 16. & Working Capital / Total Assets & $\begin{array}{l}\text { Total Current Assets - Total Current } \\
\text { Liabilities /Capital Employed }\end{array}$ & $\begin{array}{l}\text { Higher trend indicates } \\
\text { sickness }\end{array}$ \\
\hline 17. & Cash / Current Liabilities & (Cash + Bank) / Total Current Liabilities & $\begin{array}{l}\text { Lower trend indicates } \\
\text { sickness }\end{array}$ \\
\hline 18. & Quick Assets / Current Liabilities & $\begin{array}{l}(\text { Cash }+ \text { Bank }+ \text { Sundry Debtors }) / \text { Total } \\
\text { Current Liabilities }\end{array}$ & $\begin{array}{l}\text { Lower trend indicates } \\
\text { sickness }\end{array}$ \\
\hline 19. & $\begin{array}{llll}\text { Current } & \text { Assets } / \text { Current } \\
\text { Liabilities } & & & \\
\end{array}$ & $\begin{array}{l}\text { Total Current Assets / Total Current } \\
\text { Liabilities }\end{array}$ & $\begin{array}{l}\text { Lower trend indicates } \\
\text { sickness }\end{array}$ \\
\hline \multicolumn{4}{|c|}{ Turnover Ratios } \\
\hline 20. & Cash / Sales & $($ Cash + Bank) / Sales & $\begin{array}{l}\text { Higher trend indicates } \\
\text { sickness }\end{array}$ \\
\hline 21. & Account Receivables / Sales & Sundry Debtors / Sales & $\begin{array}{l}\text { Higher trend indicates } \\
\text { sickness }\end{array}$ \\
\hline 22. & Inventory / Sales & Inventory / Sales & $\begin{array}{l}\text { Higher trend indicates } \\
\text { sickness }\end{array}$ \\
\hline 23. & Quick Assets / Sales & (Cash + Bank +Sundry Debtors) / Sales & $\begin{array}{l}\text { Higher trend indicates } \\
\text { sickness }\end{array}$ \\
\hline 24. & Current Assets / Sales & Total Current Assets / Sales & $\begin{array}{l}\text { Higher trend indicates } \\
\text { sickness }\end{array}$ \\
\hline 25. & Net Worth / Sales & ( Share Capital + Reserves) / Sales & $\begin{array}{l}\text { Higher trend indicates } \\
\text { sickness }\end{array}$ \\
\hline 26. & Total Assets / Sales & Capital Employed / Sales & $\begin{array}{l}\text { Higher trend indicates } \\
\text { sickness }\end{array}$ \\
\hline
\end{tabular}

Journal of Mechanical Engineering, Vol. ME 44, No. 1, June 2014 Transaction of the Mechanical Engineering Division, The Institution of Engineers, Bangladesh 


\begin{tabular}{|c|c|c|c|}
\hline 27. & $\begin{array}{l}\text { Cash/ Fund Expenses for } \\
\text { Operation (Cash Interest) }\end{array}$ & $\begin{array}{l}\text { (Cash + Bank) / (Operating Expenses }+ \\
\text { Direct Manufacturing Expenses + Salaries } \\
\text { \& Wages })\end{array}$ & $\begin{array}{l}\text { Lower trend indicates } \\
\text { sickness }\end{array}$ \\
\hline 28. & $\begin{array}{l}\text { Defensive Interest( Quick Assets / } \\
\text { Fund Expenses for Operation ) }\end{array}$ & $\begin{array}{l}\text { Quick Assets / (Operating Expenses + } \\
\text { Direct Manufacturing Expenses + Salaries } \\
\text { \& Wages) }\end{array}$ & $\begin{array}{l}\text { Lower trend indicates } \\
\text { sickness }\end{array}$ \\
\hline Key & Adaptations/Defined as & & Remarks \\
\hline 29. & $\begin{array}{l}\text { No Credit Interval ( Net Quick } \\
\text { Assets / Fund Expenses for } \\
\text { Operations ) }\end{array}$ & $\begin{array}{l}\text { Net Quick Assets/ (Operating Expenses + } \\
\text { Direct Manufacturing Expenses + Salaries } \\
\text { \& Wages ) }\end{array}$ & $\begin{array}{l}\text { Lower trend indicates } \\
\text { sickness }\end{array}$ \\
\hline \multicolumn{4}{|c|}{ Altman's Ratios } \\
\hline 30. & $\begin{array}{l}\text { Profit Before Interest \& Tax / } \\
\text { Total Assets }\end{array}$ & Profit Before Interest /Capital Employed & $\begin{array}{l}\text { Lower trend indicates } \\
\text { sickness }\end{array}$ \\
\hline 31. & $\begin{array}{l}\text { Market Value of Equity }+ \\
\text { Preference / Total Liabilities }\end{array}$ & $\begin{array}{l}\text { (Book Value of Equity + Preference }+ \\
\text { Reserves) / ( Deferred Liabilities + Total } \\
\text { Current Liabilities ) }\end{array}$ & $\begin{array}{l}\text { Lower trend indicates } \\
\text { sickness }\end{array}$ \\
\hline \multicolumn{4}{|c|}{ Robert P Abates Ratio } \\
\hline 32. & $\begin{array}{l}\text { Inventory Cover for Deficit Quick } \\
\text { Ratio }\end{array}$ & Net Quick Assets / Inventory & $\begin{array}{l}\text { Higher trend indicates } \\
\text { sickness }\end{array}$ \\
\hline 33. & Operating Leverage & $\begin{array}{l}\text { (Sales - Stock Consumed) / Profit before } \\
\text { Interest \& tax }\end{array}$ & $\begin{array}{l}\text { Higher trend indicates } \\
\text { sickness }\end{array}$ \\
\hline 34. & Financial Leverage & $\begin{array}{l}\text { Profit before Interest \& tax / Profit } \\
\text { before Tax }\end{array}$ & $\begin{array}{l}\text { Higher trend indicates } \\
\text { sickness }\end{array}$ \\
\hline 35. & Total Leverage & Operating Leverage $\mathrm{x}$ Financial Leverage & $\begin{array}{l}\text { Higher trend indicates } \\
\text { sickness }\end{array}$ \\
\hline \multicolumn{4}{|c|}{ Short -Term Liquidity } \\
\hline 36. & $\begin{array}{l}\text { (Inventory + Sundry Debtors) / } \\
\text { (Sundry Creditors + Loans \& } \\
\text { Advances ) }\end{array}$ & $\begin{array}{l}\text { (Inventory + Sundry Debtors) / (Sundry } \\
\text { Creditors + Loans \& Advances ) }\end{array}$ & $\begin{array}{l}\text { Lower trend indicates } \\
\text { sickness }\end{array}$ \\
\hline \multicolumn{4}{|c|}{ Long -Term Liquidity } \\
\hline 37. & $\begin{array}{l}\text { Long - Term Debt / (Equity + } \\
\text { Share Capital ) }\end{array}$ & $\begin{array}{l}\text { Deferred Liabilities / ( Equity + Reserves + } \\
\text { Preference Shares ) }\end{array}$ & $\begin{array}{l}\text { Higher trend indicates } \\
\text { sickness }\end{array}$ \\
\hline 38. & Cash Flow / Long - Term Debt & $\begin{array}{l}\text { ( Profit after Tax + Interest + Depreciation } \\
) / \quad \text { (Deferred Liabilities + Interest ) }\end{array}$ & $\begin{array}{l}\text { Lower trend indicates } \\
\text { sickness }\end{array}$ \\
\hline \multicolumn{4}{|c|}{ Cost Ratios } \\
\hline 39. & Stock Consumed / Sales & Stock Consumed / Sales & $\begin{array}{l}\text { Higher trend indicates } \\
\text { sickness }\end{array}$ \\
\hline 40. & Wages \& Salaries / Sales & Wages \& Salaries / Sales & $\begin{array}{l}\text { Higher trend indicates } \\
\text { sickness }\end{array}$ \\
\hline 41. & $\begin{array}{l}\text { Direct Manufacturing Expenses / } \\
\text { Sales }\end{array}$ & Direct Manufacturing Expenses / Sales & $\begin{array}{l}\text { Higher trend indicates } \\
\text { sickness }\end{array}$ \\
\hline 42. & Operating Expenses / Sales & Operating Expenses / Sales & $\begin{array}{l}\text { Higher trend indicates } \\
\text { sickness }\end{array}$ \\
\hline 43. & ( Sales - Material Cost) / Sales & ( Sales - Material Cost ) / Sales & $\begin{array}{l}\text { Lower trend indicates } \\
\text { sickness }\end{array}$ \\
\hline 44. & $\begin{array}{l}\text { ( Sales - Material Cost ) / Capital } \\
\text { Employed }\end{array}$ & $\begin{array}{l}\text { ( Sales - Material Cost ) / Capital } \\
\text { Employed }\end{array}$ & $\begin{array}{l}\text { Lower trend indicates } \\
\text { sickness }\end{array}$ \\
\hline
\end{tabular}

Journal of Mechanical Engineering, Vol. ME 44, No. 1, June 2014 Transaction of the Mechanical Engineering Division, The Institution of Engineers, Bangladesh 